\title{
Analysis of a Fin Drag Force in a Biomimetic Underwater Vehicle
}

\section{Analiza sile otpora peraje biomitetičkog podvodnog vozila}

\author{
Pawel Piskur \\ Polish Naval Academy \\ Gdynia, Poland \\ E-mail: p.piskur@amw.gdynia.pl
}

\author{
Leszek Flis \\ Polish Naval Academy \\ Gdynia, Poland \\ E-mail: I.flis@amw.gdynia.pl
}

\author{
Joanna Sznajder \\ Polish Naval Academy \\ Gdynia, Poland \\ E-mail: j.sznajder\}@amw.gdynia.pl
}

\begin{abstract}
Summary
This article presents the analysis of fin drag force in a Biomimetic Underwater Vehicle (BUV). To carry out numerical simulations Incompressible Computational Fluid Dynamics (ICFD) solver was used. The simulation model was verified in the designed laboratory test stand. The laboratory test stand was equipped with specialized sensors for force measurements and control of fluid velocity. An average value of fluid velocity in the water tunnel was measured by specialized high accuracy ultrasonic flowmeter. A vision system was used for analysis of laminar and turbulent flows in the fluid structure interaction area. The research of fluid-structure interaction phenomena was depicted using dimensional analysis.
\end{abstract}

\section{Sažetak}

U radu se daje analiza sile otpora biomimetičkog podvodnog vozila (BUV). Za provođenje numeričkih simulacija koristio se program Računalna dinamika fluida (ICFD). Simulacijski model provjeren je u posebno izrađenom laboratoriju. Laboratorij je opremljen specijaliziranim senzorima za mjerenje sile i kontrole brzine fluida. Prosječna vrijednost brzine fluida u vodenom tunelu izmjerena je specijaliziranim ivrlo preciznim ultrasoničnim uređajem za mjerenje brzine strujanja. Sustav promatranja koristio se za analizu laminarnih i turbulencijskih strujanja u području interakcije u strukturi fluida. Istraživanje fenomena interakcije u strukturi fluida provedeno je uporabom dimenzionalne analize.

\author{
DOI 10.17818/NM/2020/3.2 \\ UDK 629 \\ $532 / 533$ \\ Original scientific paper / Izvorni znanstveni rad \\ Paper accepted / Rukopis primljen: 15. 4. 2020.
}

\section{KEY WORDS}

artificial fish

fluid structure interaction (FSI)

computational fluid dynamics (CFD)

biomimetic underwater vehicle

\section{INTRODUCTION / Uvod}

The Biomimetic Underwater Vehicles BUVs can be used in a wide variety of underwater applications [1], such as monitoring [2], investigation of sea region [3], [4] pollution detection, military operation [5], [6], [7] and protection [8], [9], [10]. In comparison to propulsion systems with the rotary propeller, the energy efficiency is limited to $70 \%$ and is $20 \%$ less than the swimming mechanism of real fish [11], [12]. The biomimetic underwater vehicles (Figure 1) are more popular due to their advantages like high-performance locomotion and manoeuvring in the water, the secrecy of operation due to the lower acoustic spectrum. The different kind of fish results from the long-time of fish evolution. The body motion function of a specific swim pattern is generally obtained from biologists [13], [14], [15]. The fish-like movement can be reproduced with fin made from a flexible material or as a connection of the rigid body with degrees of freedom depends on a specific swim pattern [16], [17], [8], [18]. Many links needed to accurately reproduce fish behaviour makes the robot model complex and its control techniques more complicated. Therefore, efforts are to be made to imitate the movement of fish with one piece of flexible fin [19]. This enables investigation of the fluid-structure interaction phenomena which is depending on many construction factors.

Due to the nonlinear fluid-structure interaction, the following method was applied. In the beginning, the fluid without any obstacles

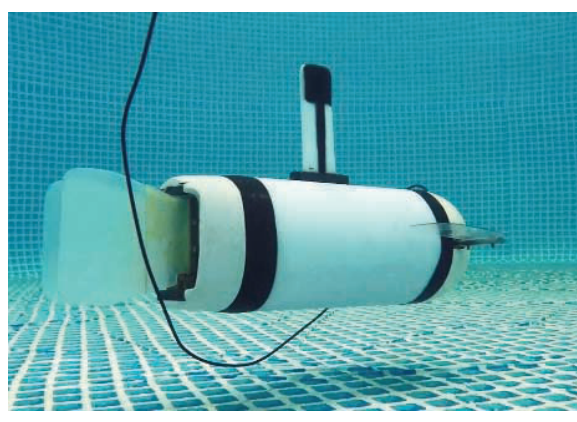

a)

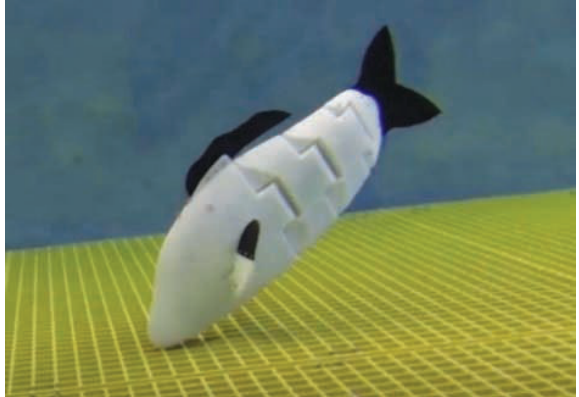

b)

Figure 1 The Biomimetic Underwater Vehicles: a) miniCyberSeal [19], b) CyberFish [15] Slika 1. Biomimetička podvodna vozila: a) miniCyberSeal [19], b) CyberFish [15] 
was measured using Particle Image Velocimetry (PIV) method. Then, examples with a cylinder were considered for verification of drag force calculations. Having done the calibration of the laboratory equipment an experiment for the fin was elaborated. The velocity region with a laminar and a turbulent flow was identified and the force for a different angle of attack was measured. The angle of attack is understood here as the angle between a fin and a fluid stream.

This paper is organized as follows. Section 2 describes a dimensional analysis for the steady-state problem. Section 3 discusses the results from numerical simulation made in LS-DYNA package and Incompressible Computational Fluid Dynamics (ICFD) solver. Section 4 provides the laboratory test stand, measurement force and fluid flow methods description. In Section 5 the experimental results with a comparison between the simulation model and experimental results are depicted. Finally, conclusions and future research are presented in Section 6.

\section{DIMENSIONAL ANALYSIS / Dimenzionalna analiza}

The dimensional analysis was conducted according to the Buckingham theory [16]. The functional relationships between the variables involved in a physical phenomenon are independent of the chosen system of units. The principle allows expressing all the information contained in the relationships between physical variables of the problem in a very compact form, using a reduced number of dimensionless variables. It reduces the number of measurements and numerical simulations needed to characterize a specific flow problem.

The analysed problem is a steady flow of an incompressible fluid of density $\rho$ and viscosity $\mu$ around the cylinder with diameter $\mathrm{R}$ (2D phenomena). The second analysis was provided for the inflexible fin mounted on the motor shaft (2D analysis) [16]. The fin angle was changed in a range compared to the fishtail movement.

Since the incompressible flow is analysed it can be assumed that the equation of continuity and momentum can be decoupled from the equation of energy, and the equations are needed to determine the pressure and the velocity fields. The force over the body involves surface integrals made up with the pressure and the velocity fields and that is why only the continuity and the momentum equations have to be considered. In addition, because the problem is analysed as a steady one, no initial conditions are required. With respect to the boundary conditions, the flow filed far away from the cylinder needed to be specified. The next assumption is connected to velocity and pressure. The far-field fluid velocity relative to the body is aligned along the $x$-direction, and the far-field pressure takes a uniform value.

According to the Pi theory, the number of independent and dependent variables should be defined. Since there is a steadystate problem the time is not taken under consideration. The independent variable is a spatial variable while the dependent variables are velocity and pressure. The drag force $(\mathrm{Fd})$ exerted by the fluid on an analysed object (a cylinder or a fin) depends on a surface, a density, a viscosity and a fluid velocity. The expression defining the drag force can be written as [20]:

$$
F_{d}=f(\rho, \mu, U, A)
$$

where:

$U$ - is the far field fluid velocity

The dimensions of the magnitudes $\mu, F_{d^{\prime}}$ can be expressed in terms of the dimensions of $\rho, A$ and $U$ as following formulas [20]:

$$
\begin{gathered}
{\left[F_{d}\right]=[\rho][\mu]\left[U^{2}\right]\left[A^{2}\right]} \\
{[\mu]=[\rho][U][A]}
\end{gathered}
$$

According to the Buckingham theory, there is $n=4$ and $k=$ 3 and consequently the number of dimensionless parameters linked to the original expression is $n+1-k=2$. These two parameters are constructed to transform $\mu, F_{d}$ into dimensionless variables using $\rho, U, A$.

$$
\text { Thus: } \quad \begin{aligned}
\Pi_{0} & =F_{d} /\left(\rho U^{2} A^{2}\right) \\
& \Pi_{1}=(\rho U A) / \mu
\end{aligned}
$$

Next, writing in the non-dimensional form the next formula can be written:

where:

$$
F_{d} /\left(\rho U^{2} A^{2}\right)=f(\rho U A / \mu)
$$

$\rho U A / \mu$ - is the flow Reynolds number;

$F_{d} /\left(\rho U^{2} A^{2}\right)$ - is the dimensionless parameter $\pi_{0}$ proportional to the drag coefficient $C_{\lambda^{\prime}}$ defined as:

$$
C_{d}=F_{d} /\left(\frac{1}{2} \rho U^{2} A\right)
$$

where:

$A$ - is a frontal area of the obstacle exposed to the flow.

In the case of the cylinder, the frontal area is $A=2 R h$, where $h$ is the height of the submerged part of the cylinder. The frontal area for a fin depends on the angle of attack according to the formula: $A=$ length ${ }^{*} \cos (a)$, where: $\alpha$ - is the angle of attack.

It can be seen that the drag force coefficient only depends on the Reynolds number. Therefore, during simulation and measurements, the Reynolds number was changed by the different fluid velocity and by different characteristic dimensions (the radius of the cylinder or the fin angle of attack).

To carry out the numerical simulations LS-DYNA Incompressible Computational Fluid Dynamics (ICFD) solver has been used. The modern and efficient solver may run as a standalone CFD solver, where only fluid dynamics effects are studied, or it can be coupled to the solid mechanics solver to study loosely or strongly coupled Fluid-Structure Interaction (FSI) problems.

First, the classic flow around a cylinder was considered to confirm the solver's ability to correctly reproduce simulated phenomena. The flow around a cylinder has been widely used both as a numerical validation test case as well as a research case [21], [22]. Depending on the Reynolds number [23], [24] the following behaviours of the flow can be identified:

$R e<50$ - a steady laminar flow with symmetric separation (Figure 2a),

$50<R e<160$ - 190 - a Karman Vortex street (Figure 2b),

$190<R e<1300$ - a laminar-turbulent transition; a turbulent separation and reattachment, a turbulent wake.

According to the available literature [22], the comparison was focused on the two values of viscosity corresponding to the Reynolds number values of $R_{\mathrm{e}}=40$ and $R_{\mathrm{e}}=100$. In the considered case, the values of pressure and lift was compared to those available in the literature and simulation to ensure correctness of the research where regime of the Reynolds number should be in a range from 100 to 120 .

For the $R_{\mathrm{e}}=40$ case, the boundary layer separation point of the laminar stationary flow was analysed as well as the reattachment length. For the $R e=100$ case the frequency of the vortex shedding was studied through the Strouhal number defined as:

where:

$$
S t=\frac{R U}{T}
$$

$R-$ is the diameter of cylinder,

$U-$ is the incoming velocity,

$T$ - is the oscillation's period. 


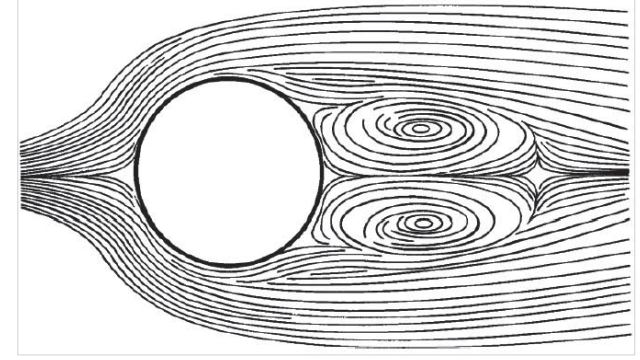

a)

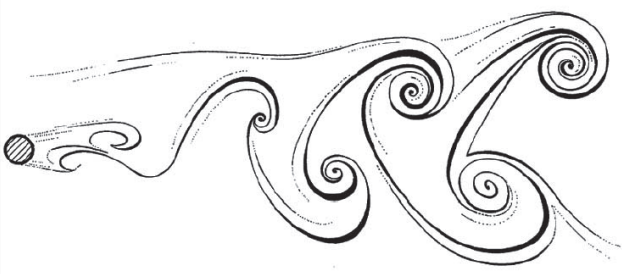

b)

Figure 2 Graphical representation of the flow around a cylinder for: a) $\operatorname{Re}=40$, b) $\operatorname{Re}=400$ [22]

Slika 2. Grafički prikaz strujanja oko cilindra za: a) $R e=40$, b) $R e=400$ [22]

\section{SIMULATION RESULTS / Rezultati simulacije}

The simulation model consists of an inflow with a prescribed velocity, an outflow with a prescribed pressure, two free slip conditions for the remaining boundaries and a non-slip condition on the cylinder. It also contains two meshing boxes which will allow a finer volume meshing around the analysed object and its immediate wake. A complete description of the model's geometry for the cylinder analysis is depicted in Figure 3a. The resulting volume mesh after running the test case is shown in Figure $3 \mathrm{~b}$.

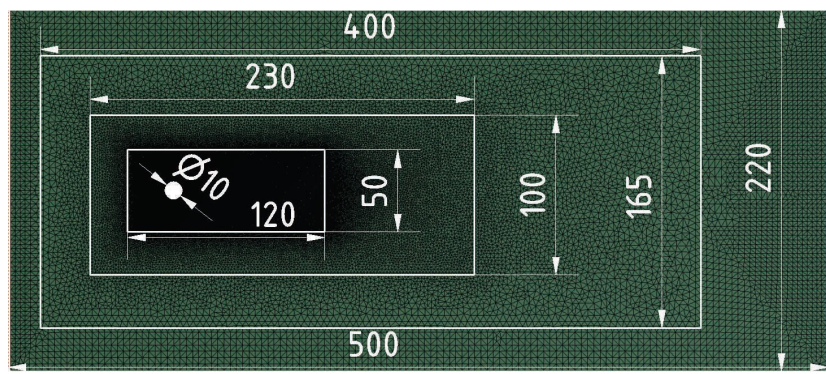

a)

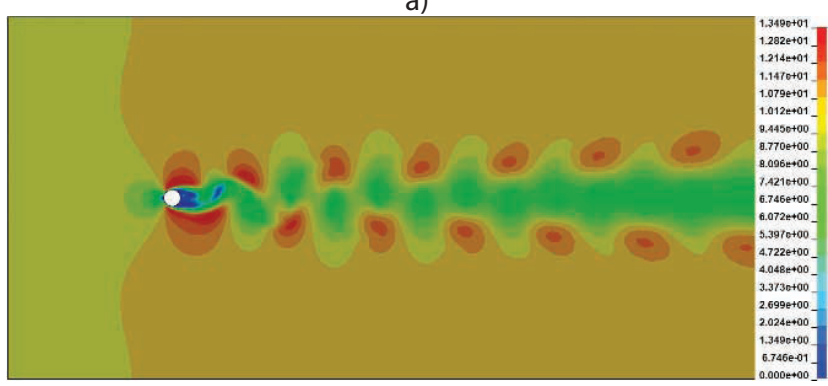

b)

Figure 3 a) The graphical example of generated mesh for the flow around a cylinder, b) A fluid velocity for Reynolds number of 100 for a cylinder

Slika 3. a) Grafički prikaz generirane mreže za strujanje oko cilindra, b) brzina fluida za Reynoldsov broj 100 za cilindar

A fluid velocity around the fin for a Reynolds number of 100 is presented in Figure $4 \mathrm{a}$, while the fluid velocity for the fin with the angle of attack $a=30$ [deg] is presented in Figure $4 \mathrm{~b}$.
Figure 5 and 6 include a comparison between the presented analysis and the results achieved from literature [21]. It can be noted that the global behaviour of the presented analysis is in good agreement with the reference results. Starting from the Reynolds number of 40 , the error regarding the total drag slowly expands going from $3.8 \%$ for $\mathrm{Re}=40$ to $7.5 \%$ for $\mathrm{Re}=2$ when comparing with the results given by [1]. This can be explained by the fact that, as the Reynolds number decreases and the viscosity increases, the hypothesis used by the Fractional Step method of the solver, (i.e. the diffusion term of the solution due to the viscosity is small compared to the convection term) is slowly reaching its limits. It can also be noted that the error regarding the lift coefficient slowly increases going from $4.1 \%$ for $\operatorname{Re}=80$ to $6.6 \%$ for $\operatorname{Re}=160$. To reduce this error, a finer mesh was used. Finally, for the Reynolds numbers of 4 and 100, some further observations can be made. For the Reynolds number of 40 , the boundary layer separation angle occurs at the angle of 540 and the distance between the reattachment point and the cylinder is equal to 2.3 which is in good agreement with the results from literature [21]. For the Reynolds number of 100 , the Strouhal number is equal to 0.165 which is in the vicinity of the results given by [21] and [25].

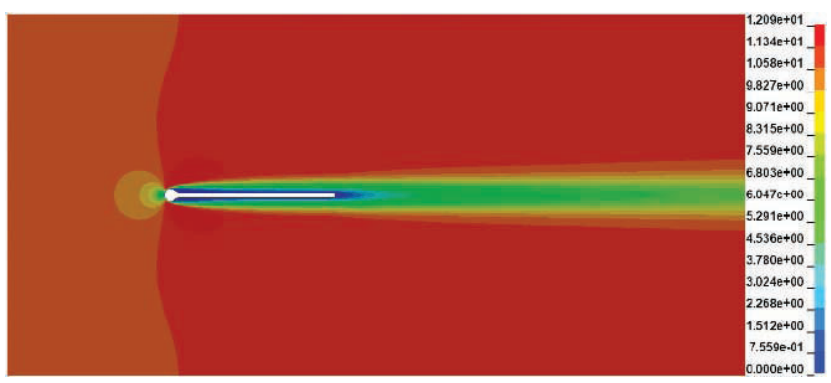

a)

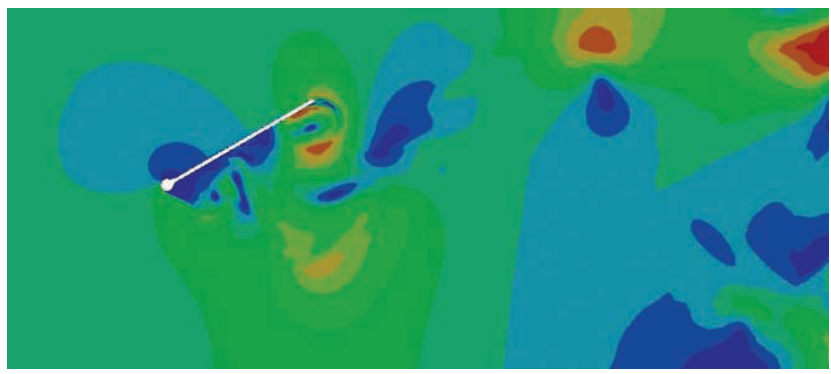

b)

Figure 4 A fluid velocity for the fin with an angle of attack: a) $a=0[\mathrm{deg}]$, b) $a=30$ [deg]

Slika 4. Brzina fluida za peraju pod kutom: a) $a=0, b) a=30$

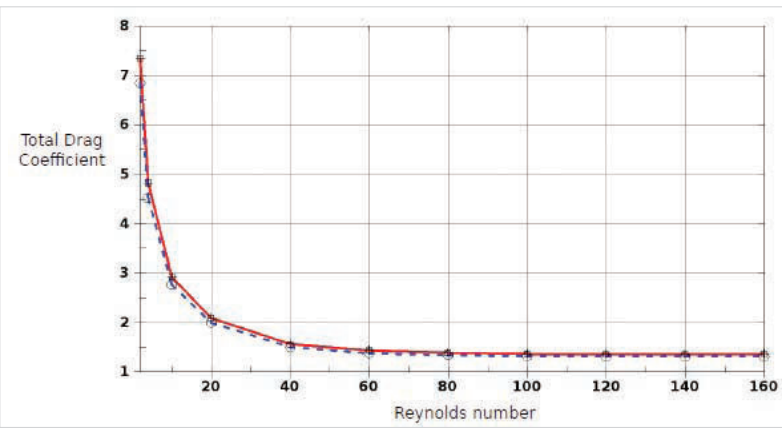

Figure 5 Comparison of the Total Drag Coefficients obtained from the presented analysis (in red) and the results (in blue) given by [21]

Slika 5. Usporedba ukupnih koeficijenata otpora dobivenih prikazanom analizom (crveno) i rezultatima (plavo) u [21] 


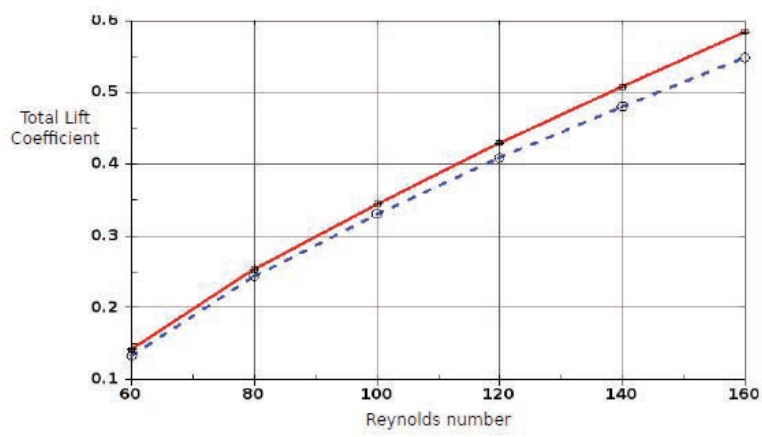

Figure 6 Comparison of the Total Lift Coefficients received from the presented analysis (in red) and the results (in blue) given by [21] Slika 6. Usporedba ukupnih koeficijenata podizanja dobivenih prikazanom analizom (crveno) i rezultatima (plavo) u [21]

In Figures 7-11 results of simulations are presented for the inflexible fin with different angle of attack. The fluid flow around the fin is presented and the drag force is depicted below each figure. The simulations were done for constant fluid velocity equal to $0.2[\mathrm{~m} / \mathrm{s}]$. The drag force from simulation model and from experiment in the water tunnel is fit enough for further analysis.

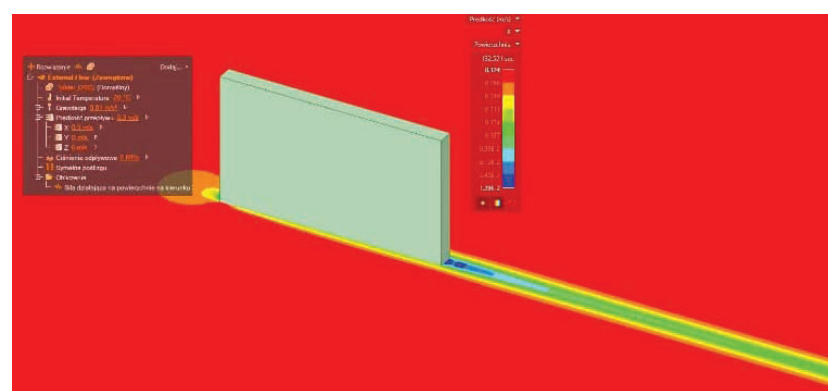

Figure 7 The drag force $\mathrm{Fd}=0.06[\mathrm{mN}]$ for the fin with $\mathrm{a}=0$ $[\mathrm{deg}], \mathrm{v}=0.2[\mathrm{~m} / \mathrm{s}]$

Slika 7. Sila otpora $F d=0.06[\mathrm{mN}]$ za peraju s $a=0, v=0.2[\mathrm{~m} / \mathrm{s}]$

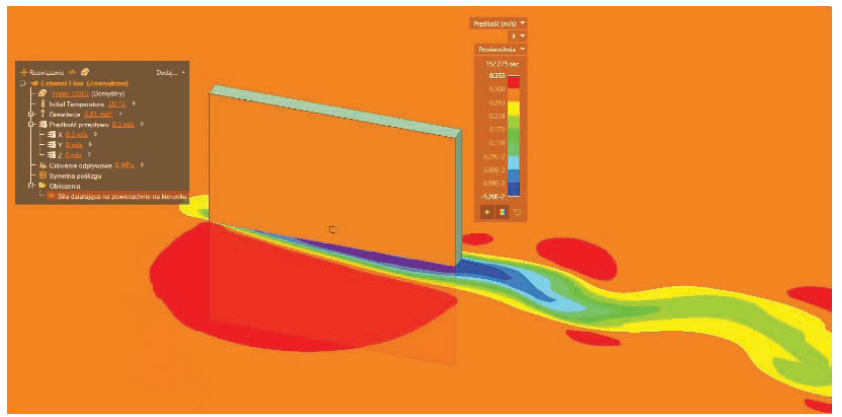

Figure 8 The drag force $\mathrm{Fd}=1.3[\mathrm{mN}]$ for the fin with $a=10$ [deg], $\mathrm{v}=0.2[\mathrm{~m} / \mathrm{s}]$

Slika 8. Sila otpora $F d=1.3[\mathrm{mN}]$ za peraju s $a=10, v=0.2[\mathrm{~m} / \mathrm{s}]$

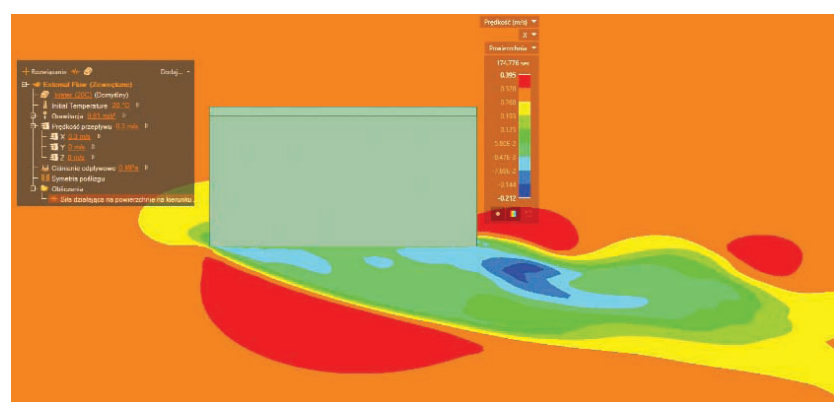

Figure 9 The drag force $\mathrm{Fd}=19.6[\mathrm{mN}]$ for the fin with $\mathrm{a}=30$ [deg], $\mathrm{v}=0.2[\mathrm{~m} / \mathrm{s}]$

Slika 9. Sila otpora Fd $=19.6[\mathrm{mN}]$ za peraju s $a=30, v=0.2[\mathrm{~m} / \mathrm{s}]$

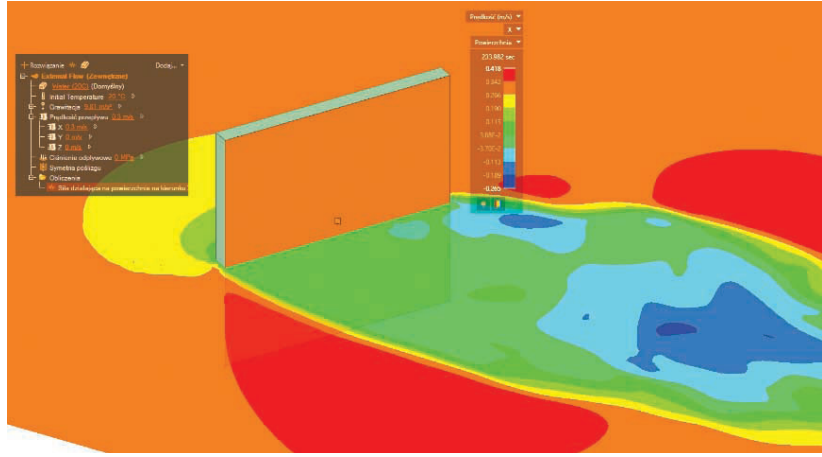

Figure 10 The drag force $\mathrm{Fd}=99.8[\mathrm{mN}]$ for the fin with $\mathrm{a}=60$ $[\mathrm{deg}], \mathrm{v}=0.2[\mathrm{~m} / \mathrm{s}]$

Slika 10. Sila otpora Fd $=99.8[\mathrm{mN}]$ za peraju s $a=60, v=0.2[\mathrm{~m} / \mathrm{s}]$

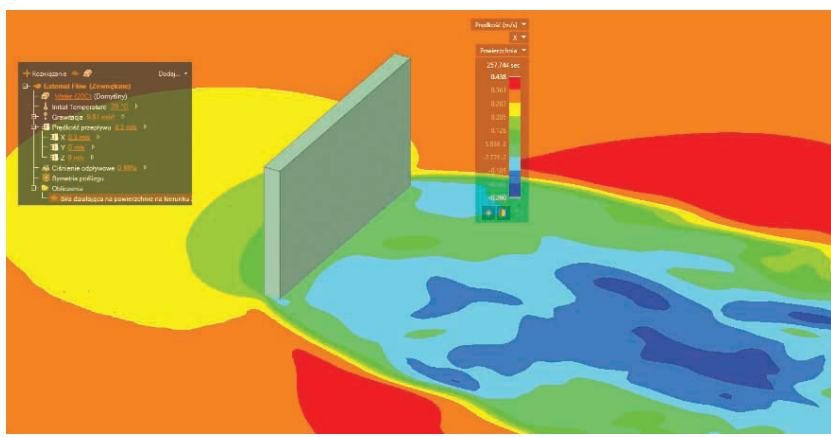

Figure 11 The drag force $\mathrm{Fd}=150.2[\mathrm{mN}]$ for the fin with $a=90$ $[\mathrm{deg}], \mathrm{v}=0.2[\mathrm{~m} / \mathrm{s}]$

Slika 11. Sila otpora Fd $=150.2[\mathrm{mN}]$ za peraju s $a=90, v=0.2[\mathrm{~m} / \mathrm{s}]$

\section{THE LABORATORY TEST STAND AND MEASUREMENT METHODS / Laboratorij za testiranje i mjerne metode}

For the verification of the simulation model, the laboratory water tunnel was prepared and equipped with sensors (Figure 12). Two measurement systems were used: the first one for the FluidStructure Interaction (FSI) force measurement and the second one for the fluid velocity control. The different shapes of the fins can be driven by the servo-mechanism (Dynamixel AX-12+) with maximal moment torque $1.5 \mathrm{Nm}$ mounted on the transparent plate. The transparent plate allows using of digital image velocimetry methods. The digital image velocimetry methods were used to determine laminar and turbulent areas of the fluid and fluid-structure interaction based on permanent markers with neutral buoyancy highlighted by a linear laser. In addition, the fluid velocity is measured using the non-invasive method with an ultrasonic flow meter. An external pump with adjustable fluid velocity was implemented in the laboratory test stand.

\subsection{Force Measurement System / Sustav za mjerenje sile}

The force interaction between a fin and fluid was measured using two precision strain gauges mounted on both sides of the water tunnel (Figure 13). The ball bearings were used for friction reduction and for direct transmission of a force from the fluid-fin interaction into the precise strain gauges system. The scheme of the force measurements is presented in Figure 13. The analogue signals from strain gauges were converted to digital form with 12-bit resolution. For analogue to digital converter input equal to $3.3 \mathrm{~V}$ the resolution of the force sensor is equal to $81 * 10-6 \mathrm{~N}$ per one bit. The total range of the measurement force determined by two strain gauges is $0.2 \mathrm{~N}$. Performed laboratory stand to measure force was presented in Figure 14. 


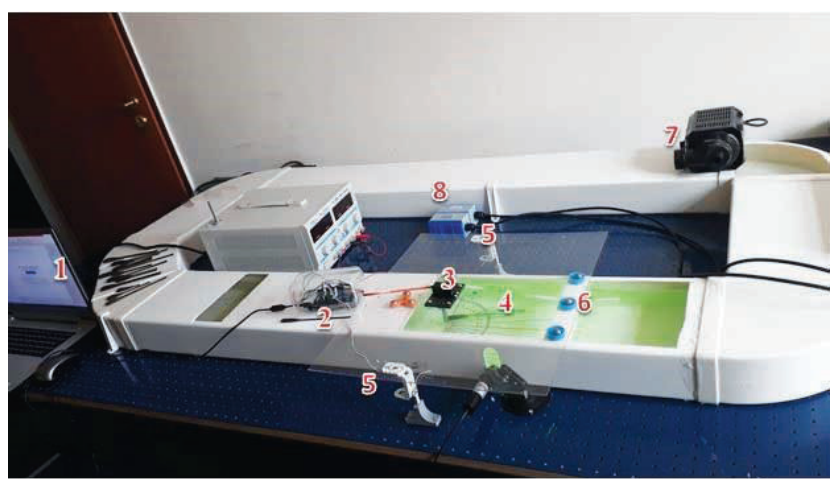

Figure 12 The laboratory water tunnel: 1 - PC, 2 - micro-controller unit (MCU), 3 - servomotor, 4 - fin, 5 - strain gauges, 6 - ball bearings, 7 - external water pump, 8 - ultrasonic flowmeter

Slika 12. Vodeni tunel u laboratoriju: 1 - $P C, 2$-jedinica za mikrokontrolu(MCU), 3 - servomotor, 4 - peraja, 5 -dinamometri, 6 - kuglični ležajevi, 7-vanjska pumpa vode, 8 - ultrasonični mjerač strujanja

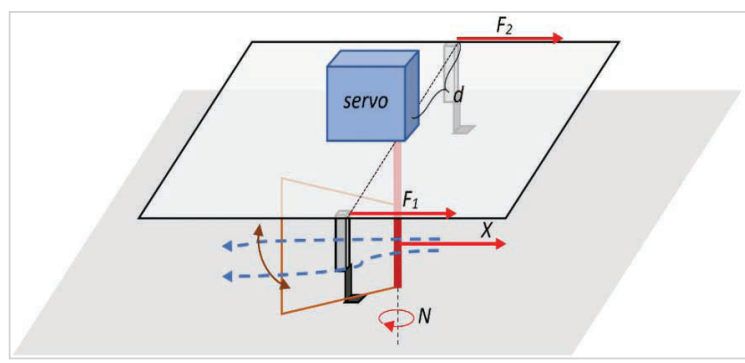

a)

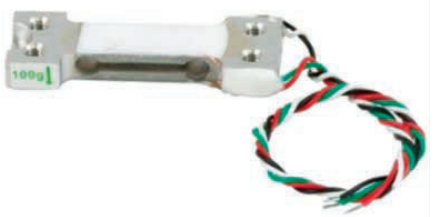

b)

Figure 13 a) Measurement scheme of force $X$ and moment of force $\mathrm{N}$ on the basis of forces $\mathrm{F} 1$ and $\mathrm{F} 2$ obtained from the precise strain gauges; $b$ ) the photo of strain gauge for force measurement up to $0.1 \mathrm{~N}$

Slika 13. a) Shematski prikaz mjerenja sile X i trenutka N na temelju sila F1 i F2 dobivenih s pomoću preciznih dinamometara; b) slika dinamometra za mjerenje sile do $0.1 \mathrm{~N}$

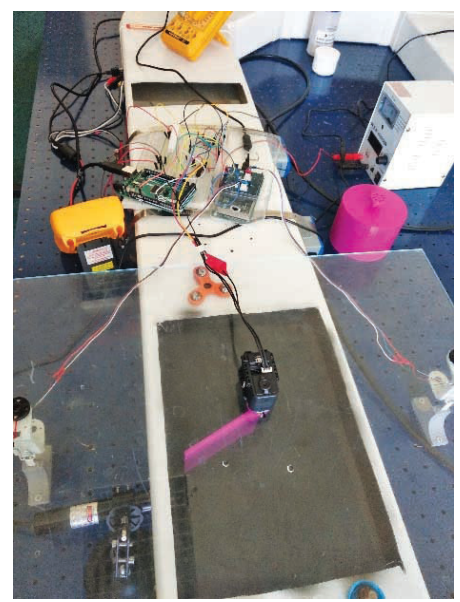

Figure 14 The laboratory test stand with the cylinder and the fin (both are purple color) for the drag force measurements Sluka 14. Laboratorij s cilindrom i perajom (oboje označeno ljubičastom bojom) za mjerenje sile otpora

\subsection{Particle Image Velocimetry (PIV) Measurement System / Sustav mjerenja s pomoću velocimetrije slike čestica (PIV)}

The camera with slow-motion option was used for tracking the permanent marker (with neutral buoyancy) highlighted by green linear laser (Figure 15a). Next, the movie was converted to the series of images and the format of each image was changed to the grey one (Figure 15b). To remove uneven illumination issue (such as shadows) the histogram matching algorithm was applied.

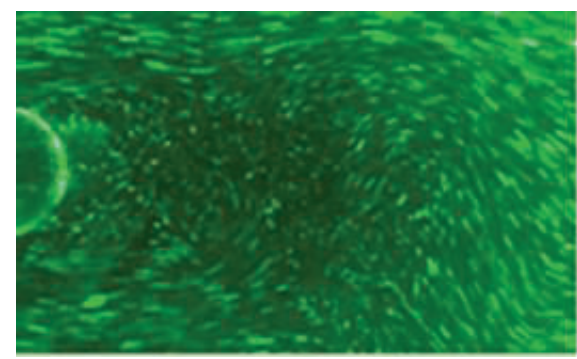

a)

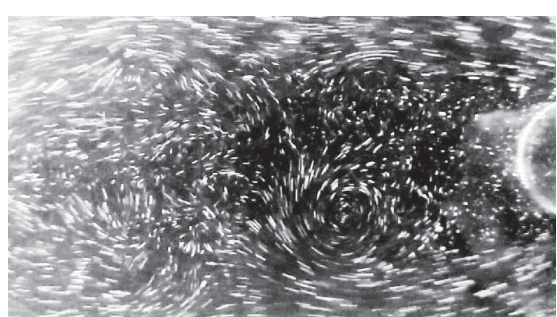

b)

Figure 15 The fluid flow behind the cylinder with permanent markers highlighted by the linear laser, a) the picture made during laboratory tests, $b$ ) the picture after conversion to the grayscale and the histogram equalization

Slika 15. Strujanje fluida iza cilindra s permanentnim markerima označenima linearnim laserom, a) slika nastala tijekom laboratorijskih testova, b) slika nakon pretvaranja u sivu skalu i izjednačavanja histograma

The normalized cross-correlation function based on the grayscale images was used to determine the template displacement in each frame from the vision system. The template size was chosen in relation to the fluid velocity, the area of investigation and the camera performance. For the fluid velocity calculation, the algorithms of normalized crosscorrelation function were used [26]:

$$
\gamma(u, v)=\frac{\sum_{x, y}\left[f(x, y)-\bar{f}_{u, v}\right][t(x-u, y-v)-\bar{t}]}{\left\{\sum_{x, y}\left[f(x, y)-\bar{f}_{u, v}\right]^{2} \sum_{x, y}[t(x-u, y-v)-\bar{t}]^{2}\right\}^{0.5}}
$$

where:

$f$ - is the image,

$\bar{t}-$ is the mean of the template,

$\bar{f}_{u, v}$ - is the mean of $f(x, y)$ in the region under template,

$u$ - is the fluid velocity along the measured fluid path,

$v$ - is the fluid velocity perpendicular to the measured fluid path.

For the best-correlated images the normalized crosscorrelation function achieves the global maximum (Figure 16). Analysis of the maxima global and local functions (7) allows checking whether the template size is suitable for the desired accuracy. The best solution of the velocity calculation is for the one global maximum. In Figure 16 an example of normalized two-dimensional cross-correlation calculation results is presented for the image with resolution 480x640 pixels. 


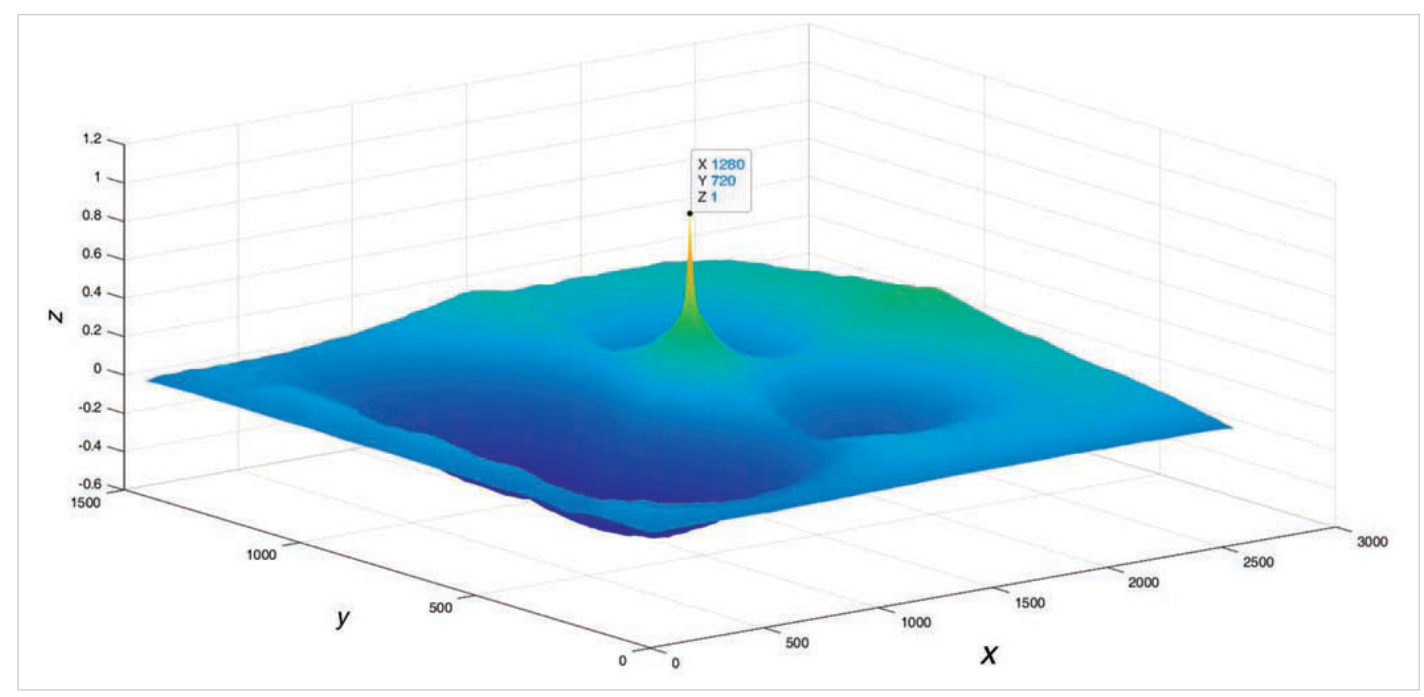

Figure 16 The result of normalized cross-correlation calculation Slika 16. Rezultat izračuna normalizirane unakrsne korelacije

The fluid velocity was verified in comparison to measurements made by a high-class accuracy ultrasonic flowmeter using the normalized cross-correlation function. For the calibration process, the undisturbed flow was taken into consideration. In the next step of research, the normalized cross-correlation function will be used for analysing the laminar and the turbulent area and their impact on the undulating propulsion system characteristics [27], [8].

\section{EXPERIMENT RESULTS / Rezultati eksperimenta}

The drag force was calculated analytically according to the equation (5) and then compared with the results from the simulation and from the measurements. The drag coefficient for cylinder was adopted from literature [24] $\mathrm{Cd}=0.45$. Because the results obtained from the analytic formula, from the simulation model designed in LS-DYNA and from the measurements in the laboratory water tunnel were very similar (Figure 17), it was assumed that the simulation model and the laboratory test stands are ready for the fin analysis. A restriction is only connected with the minimal value of the force that can be measured by strain gauges. It means that the force measurements system is too low for the fluid velocity below $0.1 \mathrm{~m} / \mathrm{s}$.

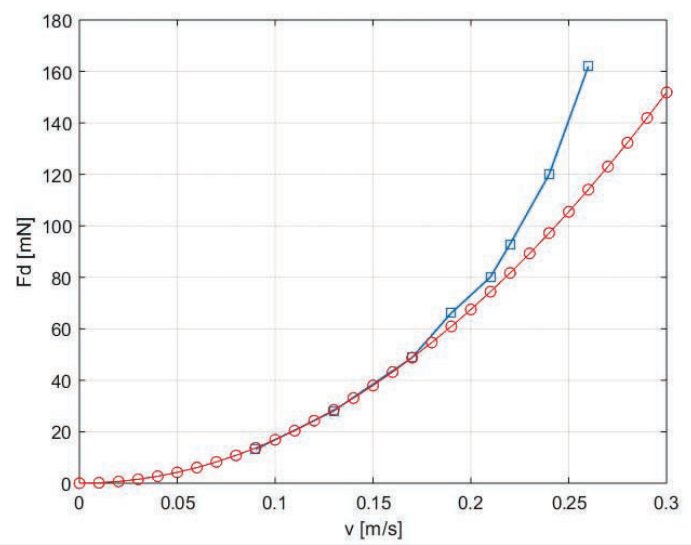

Figure 17 The drag force for the cylinder based on the analytical relations (red colour line with circle makers) and from the measurement experiment (blue line with square markers) Slika 17. Sila otpora cilindra na temelju analitičkih odnosa (crvena crta s okruglim markerima) i mjernog eksperimenta (plava crta s kvadratnim markerima)
Having done the verification for the cylinder the fin analysis was performed. In Figure 18 results from measurement in the water tunnel are depicted. The maximal velocity achieved from the experiments was dependent on the angle of attack. For the higher angle of attack the fluid velocity was lower due to the losses in the water tunnel. For the $a=30$ [deg] the maximal fluid velocity $v=0.3$ $[\mathrm{m} / \mathrm{s}]$, while for the $\mathrm{a}=90[\mathrm{deg}]$ the maximal fluid velocity was equal to $v=0.21[\mathrm{~m} / \mathrm{s}]$. For the $a=0[\mathrm{deg}]$, the fluid flow velocity was very similar to the flow without any obstacles, but the strain gauge system was unable to measure such a low force acting between the fluid and the fin. Due to measuring range of the strain gauges some measurement errors occurred for the fluid flow below 0.1 $[\mathrm{m} / \mathrm{s}]$. On the other hand, the differences occurred for the velocity higher than $0.2[\mathrm{~m} / \mathrm{s}]$ were caused by the turbulent flow made by narrowing of the water tunnel. That is why the verification of the simulation model for the fin was made for the velocity of $0.2[\mathrm{~m} / \mathrm{s}]$.

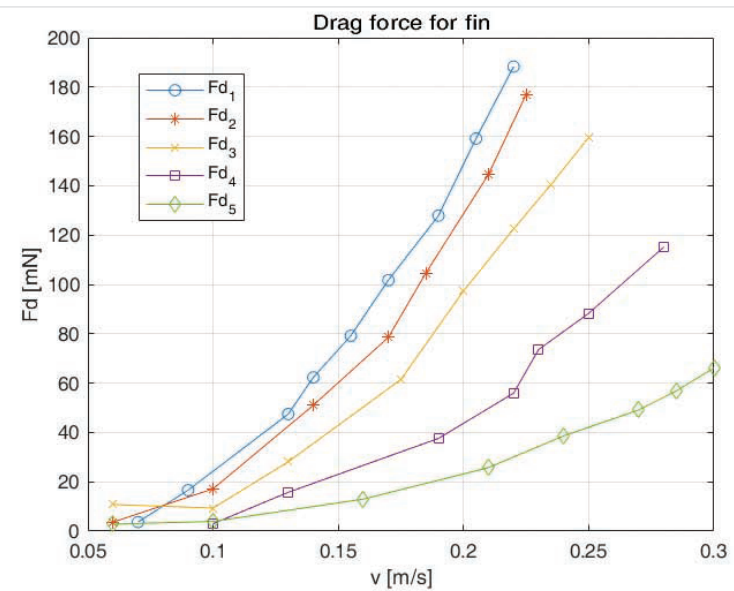

Figure 18 The drag force produced by the fin for different angle of attack (results of measurement in the water tunnel)

Slika 18. Sila otpora koju stvara peraja pod različitim kutovima (rezultati mjerenja u vodenom tunelu)

\section{CONCLUSIONS / Zaključci}

The presented dimensional analysis allows expressing all the information contained in the relationships between physical variables of the problem in a very compact form, using a reduced number of dimensionless variables. 
The laboratory water tunnel was depicted focusing on applied measurement sensors and methods of analysis. The cross-correlation method was presented and discussed. This method will be used for visual testing of the fluid-structure interaction. What is more, the presented vision system will be used for the impact of design parameters on the analysis of undulating propulsion characteristics. The drag force analysis for the cylinder and the inflexible fin shows that the simulation model can be developed for mechanical aspects for the flexible fin consideration and the propulsion force analysis.

The simulation model made in LS-DYNA package and Incompressible Computational Fluid Dynamics (ICFD) solver was presented and results were discussed. Although the simulation method has been successfully verified, it is one of the stages of testing fluid-structure interaction. In the next step of research, a mechanical solver will be implemented to study material fin flexibility. By using vision system not only the fluid velocity can be analysed, but the flexible fin deflection can be estimated. The final results of this research will be the set of characteristics with undulating system properties for a one-piece flexible fin.

\section{Acknowledgement / Zahvala}

The paper is supported by the Research Grant of the Polish Ministry of Defence entitled "Model studies of the characteristics of a undulating propulsion system".

Calculations were carried out at the Academic Computer Centre in Gdańsk.

\section{REFERENCES / Literatura}

[1] Connor, F., White, Y. L. (2016). "Human vs robot: Comparing the viability and utility of autonomous underwater vehicle for the acoustic telemetry tracking of marine organism". Journal of Experimental Marine Biology and Ecology, Vol. 485, pp. 112-118. https://doi.org/10.1016/j.jembe.2016.08.010

[2] Carey, J. D. (2016). "Results from an autonomous underwater vehicle towed hydrophone array experiment in Nantucket Sound". The Journal of the Acoustical Society of America, Vol. 120, No. 2. https://asa.scitation.org/ doi/10.1121/1.2219106.

[3] Piskur, P., Szymak, P. (2017). "Algorithms for passive detection of moving vessels in marine environment". Journal of Marine Engineering \& Technology, Vol. 16, No. 4, pp. 377-385. https://doi.org/10.1080/20464177.2017.1398483

[4] Piskur, P., Gasiorowski, M. (2020). "Digital Signal Processing for Hydroacoustic System in Biomimetic Underwater Vehicle". OUR SEA: International Journal of Maritime Science \& Technology, Vol. 67, No. 1, pp. 14-18. https://doi. org/10.17818/NM.

[5] Szymak, P., Gasiorowski, M. (2020). "Using Pretrained AlexNet Deep Learning Neural Network for Recognition of Underwater Objects". OUR SEA International Journal of Maritime Science \& Technology, Vol. 67, No. 1, pp. 9-13. https://doi.org/10.17818/NM

[6] Morawski, M., Słota, A., Zając, J., Malec, M, Krupa, K. (2017). “Hardware and low-level control of biomimetic underwater vehicle designed to perform ISR tasks". Journal of Marine Engineering \& Technology, Vol. 16, No. 4. https://doi. org/10.1080/20464177.2017.1387089

[7] Szymak, P., Praczyk, T. (2016). "Software architecture of biomimetic underwater vehicle". Ground/Air Multisensor Interoperability, Integration, and Networking for Persistent ISR VII. Proceedings of SPIE, Vol. 9831. https:// doi.org/10.1117/12.2225587
[8] Wang, C. L. (2017). "Optimization of the Kinematic Model for Biomimetic Robotic Fish with Rigid Headshaking Mitigation". Robotics, Vol. 6, No. 4.https://doi.org/10.3390/robotics6040030

[9] Zak, B., Hozyn, S. (2017). "Local image features matching for real-time seabed tracking applications". Journal of Marine Engineering and Technology, Vol. 16, No. 4, pp. 273-282. https://doi.org/10.1080/20464177.2017.1386266

[10] Malec, M., Morawski, M., Szymak, P., Trzmiel, A. (2014). “Analysis of Parameters of Traveling Wave Impact on the Speed of Biomimetic Underwater Vehicle". Solid State Phenomena, Vol. 210, pp. 273-279. https://doi.org/10.4028/www. scientific.net/SSP.210.273

[11] Wang, J., Tan, X. (2014). "Averaging of Tail-Actuated Robotic Fish Dynamics through Force and Moment Scaling". IEEE Transactions on Robotics, Vol. 31, No. 4, pp. 906-917. https://doi.org/10.1109/TRO.2015.2433539

[12] Morawski, M., Malec, M., Zajac, J. (2014). “Development of CyberFish - Polish Biomimetic Unmanned Underwater Vehicle BUUV". Applied Mechanics and Materials, Vol. 613, pp. 76-82. DOI: 10.4028/www.scientific.net/AMM.613.76 https://doi.org/10.4028/www.scientific.net/AMM.613.76

[13] Ozmen Koca, G., Bal, C., Korkmaz, D., Bingol, M. C., Ay, M., Akpolat, Z. H., Yetkin S. (2018). "Three-Dimensional Modeling of a Robotic Fish Based on Real Carp Locomotion". Applied Sciences, Vol. 8, No. 2, p. 180. https://doi.org/10.3390/ app8020180

[14] Liu, J., Hu, H. (2010). "Biological Inspiration: From Carangiform Fish to MultiJoint Robotic Fish". Journal of Bionic Engineering, Vol. 7, pp. 35-48. https://doi. org/10.1016/S1672-6529(09)60184-0

[15] Taylor, G. K., Nudds, R. L., Thomas, A. R. L. (2003). "Flying and Swimming Animals at a Strouhal Number Tuned for High Power Efficiency". Nature, Vol. 425, pp. 707-710. https://doi.org/10.1038/nature02000

[16] Lauder, G. V. (2006). "Hydrodynamics of undulatory propulsion". Fish Physiol., Vol. 23, pp. 425-468. https://doi.org/10.1016/S1546-5098(05)23011-X

[17] Lighthill, M. J. (1960). "Note on the swimming of slender fish". Journal of Fluid Mechanics, Vol. 9, No. 2, pp. 305-317. https://doi.org/10.1017/ S0022112060001110

[18] Szymak, P., Morawski, M., Malec M. (2012). “Conception of Research on Bionic Underwater Vehicle with Undulating Propulsion". Solid State Phenomena, Vol. 180, pp. 160-167. https://doi.org/10.4028/www.scientific.net/SSP.180.160

[19] Szymak, P., Przybylski, M. (2018). "Thrust Measurement of Biomimetic Underwater Vehicle with Undulating Propulsion". Scientific Journal of Polish Naval Academy, Vol. 213, No. 2, pp. 81-127. https://doi.org/10.2478/ sjpna-2018-0014

[20] Potter, M. C., Wiggert, D. C., Ramadan, B. H. (2015). Mechanics of Fluids. 5th Edition. Stamford, CT: Cengage Learning.

[21] An-Qing, B., Hua-Shu, D. (2015). "Simulation and stability study of the flow around a cylinder in infinite domain". Procedia Engineering, Vol. 126, pp. 6872. https://doi.org/10.1016/j.proeng.2015.11.180

[22] Baracu, T., Grigoras-Benescu, S. (2014). "Computational analysis of the flow around cylinder and of the drag force". Proceeding in The 2nd Conference of the Young Researchers from TUCEB (Technical University of Civil Engineering of Bucharest, Romania), pp. 16-26.

[23] Zhou, C. Y., Graham, J. M. R. (2000). "A numerical study of cylinder sin wave sand currents". Journal of Fluids and Structures, Vol. 14, No. 3, pp. 403-428. https://doi.org/10.1006/jfls.1999.0276

[24] Park J., Kwon, K., Choi, C. (1998). "Numerical solutions of flow past a circular cylinder at Reynolds numbers up to 160 ". KSME international Journal, Vol. 12 No. 6, pp.1200-1205. https://doi.org/10.1007/BF02942594

[25] Borazjani, I., Sotiropoulos, F. (2008). "Numerical investigation of the hydrodynamics of carangiform swimming in the transitional and inertial flow regimes". Journal of Experimental Biology, Vol. 211, pp. 1541-1558. https:// doi.org/10.1242/jeb.015644

[26] Haralick, R. M. (1992). Computer and Robot Vision. Vol. II. Boston, MA Addison-Wesley.

[27] Krishnadas A., Ravichandran, S., Rajagopal, P. (2018). "Analysis of biomimetic cadual fin shapes for optimal propulsive efficiency". Ocean Engineering, Vol. 153, pp. 132-142. https://doi.org/10.1016/j.oceaneng.2018.01.082 